Jurnal Pemberdayaan: Publikasi Hasil Pengabdian kepada Masyarakat

Vol. 3, No. 2, Agustus 2019, Hal. 184-190

ISSN: 2580-2569; e-ISSN: 2656-0542

DOI: https://doi.org/10.12928/jp.v3i2.942

\title{
Pendampingan guru SMA Kabupaten Klaten dalam rangka publikasi ilmiah dengan E-Balada
}

\author{
Wiharto $^{1}$, Siti Fatimah ${ }^{2}$, Esti Suryani ${ }^{1}$ \\ Universitas Sebelas Maret, Jl. Ir Sutami No.36 A, Surakarta, Jawa Tengah ${ }^{1}$ \\ Universitas Muhammadiyah Surakarta, Jl. A. Yani, Pabelan,Sukoharjo, Jawa Tengah² \\ Email: wiharto@staff.uns.ac.id
}

\begin{abstract}
ABSTRAK
Peningkatan kualitas kompetensi guru menjadi prioritas dalam rangka mewujudkan pendidikan yang bermutu dan profesional. Pemerintah mewajibkan guru yang hendak meningkatkan pangkat golongannya atau mendapatkan tunjangan sertifikasi dituntut untuk menulis artikel. Artikel yang dihasilkan diwajibkan untuk dipublikasikan. Untuk melaksanakan hal tersebut maka guru dituntut untuk menulis artikel, baik artikel yang berdasarkan ide/gagasan, artikel berdasarkan pengamatan/penelitian, maupun artikel berdasarkan literasi. Adanya kewajiban tersebut, kebanyakan guru yang hendak naik pangkat/golongan masih mengalami kesulitan untuk memulai menulis artikel. Hal ini dikarenakan oleh beberapa faktor, antara lain adalah ide yang sukar dikembangkan, pengolahan data yang rumit, ketidaktahuan penggunaan fasilitas teknologi informasi yang sudah ada dalam rangka mempermudah penulisan, dan faktor pribadi yang tidak mau berkembang. Guru sekolah SMA Negeri Karangdowo Kabupaten Klaten, sebagian besar sudah tersertifikasi. Sebagian dari mereka belum terlalu mahir dalam penggunaan teknologi informasi untuk membantu proses kenaikan pangkat atau perbaikan kualitas pembelajaran. Solusi dari permasalahan tersebut salah satunya adalah melalui program E-balada (Pembelajaran dan Pendampingan dengan menggunakan teknologi informasi). Program E-balada merupakan program pendampingan penggunaan teknologi informasi seperti optimalisasi penggunaan tampilan menu pada microsoft word yang sudah ada, penggunaan zotero, schoology. Guru dapat memanfaatkan program ini sebagai alat bantu. Program E- balada ini dapat meningkatkan kualitas kompetensi mengajar maupun kualitas dari segi profesinya.
\end{abstract}

Kata kunci : pendampingan, guru, SMA, artikel ilmiah, E-balada

\begin{abstract}
Improving the quality of teacher competencies is a priority in order to realize quality and professional education. The government requires teachers who want to improve their class rank or get certification allowance are required to write an articles. The resulting article is required to be published. To do this, the teacher is required to write articles, both articles based on ideas, articles based on observation / research, and articles based on literacy. The existence of these obligations, most teachers who want to be promoted / group still have difficulty to start writing articles. This is due to several factors, including ideas that are difficult to develop, complicated data processing, ignorance of the use of existing information technology facilities in order to facilitate writing, and personal factors that do not want to develop. Most Karangdowo Public High Schools in Klaten Regency are already certified. Some of them are not yet very proficient in the use of information technology to help the promotion process or improve the quality of learning. One of the solutions to these problems is through the EBALADAprogram (Learning and Assistance using information technology). The E-BALADAprogram is an assistance program for the use of information technology such as optimizing the use of menu displays on existing Microsoft Word, using Zotero, schoology. The teacher can use this program as a tool. The E-BALADAprogram can improve the quality of teaching competencies and the quality of the profession.
\end{abstract}

Keywords : mentoring, teacher, high school, article, E-balada 


\section{PENDAHULUAN}

Guru memegang peranan penting dalam rangka mencerdaskan kehidupan bangsa. Oleh sebab itu berbagai kebijakan dan kegiatan telah dan akan terus dilakukan untuk meningkatkan karir, mutu, penghargaan, dan kesejahteraan guru. Harapannya mereka akan lebih mampu bekerja sebagai tenaga profesional dalam melaksanakan tugas dan tanggung jawabnya (Widoyoko, 2008a). Salah satu kebijakan penting adalah kaitannya dengan promosi kenaikan pangkat/jabatan guru dengan prestasi kerja. Prestasi kerja guru tersebut sesuai dengan tupoksinya berada dalam bidang kegiatannya antara lain adalah pendidikan, proses pembelajaran, pengembangan profesi, dan penunjang proses pembelajaran. Keputusan Menteri Pendayagunaan Aparatur Negara Nomor 84/1993 tentang Jabatan Fungsional Guru dan Angka Kreditnya, serta Keputusan bersama Menteri Pendidikan dan Kebudayaan dan Kepala BAKN Nomor 0433/1993 nomor 25 tahun 1993 tentang Petunjuk Pelaksanaan Jabatan Fungsional Guru dan Angka Kreditnya, pada prinsipnya bertujuan untuk membina karier kepangkatan dan profesionalisme guru. Kebijakan itu diantaranya mewajibkan guru untuk melakukan keempat kegiatan yang menjadi bidang tugasnya, dan hanya bagi mereka yang berhasil melakukan kegiatan dengan baik diberikan angka kredit. Selanjutnya angka kredit itu dipakai sebagai salah satu persyaratan peningkatan karir. Penggunaan angka kredit sebagai salah satu persyaratan seleksi peningkatan karir. Penggunaan angka kredit sebagai salah satu persyaratan seleksi peningkatan karir, bertujuan memberikan penghargaan secara lebih adil dan lebih profesional terhadap kenaikan pangkat yang merupakan pengakuan profesi serta kemudian memberikan peningkatan kesejahteraanya. Sebagai tindak lanjutnya adalah guru dituntut dari berbagai pihak untuk dapat melaksanakan Penelitian Tindakan Kelas (Darmalaksana, 2017).

Tuntutan tersebut terkait dengan kebutuhan akreditasi sekolah, kenaikan pangkat, program BOS (Bantuan Operasional Sekolah) dan sertifikasi sebagai pendidik. Tuntutan tersebut pada satu sisi mendorong para guru untuk berusaha melaksanakan penelitian di sekolahnya demi memenuhi tuntutan, namun tak sedikit guru-guru yang putus asa karena tidak dapat melaksanakan kegiatan tersebut. Pada hal kebutuhan tersebut menjadi salah satu syarat penentu untuk dapat tidaknya seorang guru yang sudah berpangkat Pembina (IVA) naik ke jenjang yang lebih tinggi. Keresahan yang dialami oleh para guru pada satu sisi mendorong upaya positif para guru untuk mau belajar dan meneliti secara wajar demi mendapatkan Kredit Poin untuk dapat naik pangkat ke jenjang lebih tinggi, namun ada sebagian guru yang memilih jalan pintas dengan memesan karya ilmiah pada pihak-pihak tertentu. Dampaknya, citra guru tercoreng dengan munculnya PAK (Penilaian Angka Kredit) palsu. Kejadian yang mencoreng citra sebagian guru tersebut sebenarnya tidak perlu terjadi jika para penentu kebijakan baik swasta maupun negeri mau dengan sungguh- sungguh memperhatikan kebutuhan guru dalam mengembangkan kemampuan menulis karya ilmiah di antaranya Penelitian Tindakan Kelas (Widoyoko, 2008b).

Bagi guru yang masih ada motivasi untuk dapat naik pangkat ke golongan lebih tinggi setelah IV/a atau menambah skor portofolio dalam sertifikasi guru dalam jabatan adalah adanya keinginan untuk menulis. Motivasi menjadi faktor penentu dari kelanjutan untuk mewujudkan keinginan itu. Seperti disebutkan dalam SK Menpan No. 84/1993 tanggal 24 Desember 1993 tentang jabatan fungsional guru dan angka kreditnya, bahwa untuk kenaikan pangkat/jabatan lebih tinggi dari Pembina/IVa menjadi Pembina Tingkat I/IVb atau tingkatan yang lebih tinggi lagi diwajibkan sekurang-kurangnya 12 angka kredit unsur pengembangan profesi. Kalau butir ini tidak dipenuhi, maka pangkat guru akan mentok sampai golongan IV/a (Alam, 2015).

Salah satu sekolah di Kabupaten Klaten yang memiliki keadaan yang sama dengan uraian di atas adalah seperti SMA Negeri Karangdowo. Permasalahan yang dominan muncul adalah kebanyakan guru akan mengajukan kepangkatan tetapi terkendala dalam penulisan artikel, 
penggalian ide, dan mengolah data. Mereka belum mahir dalam pemanfaatan teknologi informasi untuk mempermudah pengerjaaanya. Selain itu mereka juga belum bisa mengoptimalkan adanya diversifikasi metode pembelajaran dengan memanfaatkan teknologi informasi. Berdasarkan analisis situasi ini maka dengan adanya Program E- balada ini akan memberikan solusi yang bisa menekan permasalahan yang dialami oleh sebagian guru di SMA Negeri Karangdowo Kabupaten Klaten. Program E- balada adalah program pembelajaran dan pendampingan dengan menggunakan teknologi informasi. Program E- balada merupakan program pendampingan penggunaan teknologi informasi seperti optimalisasi penggunaan tampilan menu pada microsoft word yang sudah ada, penggunaan Zotero dan schoology.

\section{METODE}

Tahapan yang dilaksanakan dalam kegiatan Program Kemitraan Masyarakat E-balada terdiri dari lima tahapan. Tahap pertama adalah survey dan studi analisis situasi SMA Negeri 1 Karangdowo Kabupaten Klaten. Kegiatan ini meliputi pendataan jumlah guru, mendata golongan/pangkat, mendata jumlah artikel yang sudah dihasilkan, mendata aktifitas metode pembelajaran yang sering dilakukan oleh guru, dan data lain untuk mendukung keberjalanan Program E-balada. Pada tahap ini dilakukan oleh Tim Pengabdian PKM dari kepakaran bidang Teknik Informatika dan Teknik Kimia untuk membantu dalam mendata maupun menggali permasalahan. Tahap kedua adalah introduksi sosialisasi Program E- balada. Pada tahap ini akan dijelaskan tentang optimalisasi penggunaan menu-menu yang ada pada program microsoft word. Selain itu juga akan dilakukan introduksi tentang media-media yang bisa digunakan dalam rangka membantu pembuatan artikel ilmiah, pengolahan data, sitasi suatu artikel. Tahap ketiga adalah edukasi dan pendampingan penggunaan E-balada. Pada tahap ini guru SMA Negeri Karangdowo diberikan edukasi dan pendampingan penggunaan mediamedia dalam E- balada. Hal ini dilakukan selama beberapa kali pertemuan agar menghasilkan luaran yang diharapkan. Luaran tersebut adalah guru dapat memanfaatkan dan menggunakan Program E-balada untuk mempermudah tugasnya. Tahap kelima adalah pemantauan dan evaluasi berkala kegiatan Program E- balada. Pada tahap ini selain dilakukan pemantauan juga dilakukan evaluasi keberhasilan Program E-balada.

\section{HASIL, PEMBAHASAN, DAN DAMPAK}

Berdasarkan survey di SMA Negeri 1 Karangdowo bahwa sebanyak 74 guru yang memiliki golongan IIIa sampai dengan golongan IIId adalah 52 orang. Golongan IVa sebanyak 4 orang, selain itu adalah Guru Tidak Tetap (GTT). Berdasarkan data tersebut terlihat banyaknya guru yang masih berada pada golongan IIIa sampai dengan IIId belum menaikkan pangkat/golongannya karena terkendala jumlah angka kredit yang kurang. Angka kredit yang masih kurang ini salah satu faktornya adalah artikel hasil penelitian tindakan kelas atau artikel hasil tulisan. Wawancara yang dilakukan dari sebagian guru, mengatakan bahwa tuntutan untuk menulis ini dirasa sangat sulit. Hal ini dikarenakan beberapa faktor antara lain adalah ide yang sukar dikembangkan, pengolahan data yang rumit, ketidaktahuan penggunaan fasilitas teknologi informasi yang sudah ada dalam rangka mempermudah penulisan, dan faktor pribadi yang tidak mau berkembang. Kemajuan teknologi informasi merupakan salah satu media yang bisa digunakan untuk meningkatkan eksistensi bagi guru baik dari segi profesionalismenya maupun kualitas pembelajarannya

Kegiatan Program Kemitraan Masyarakat dengan E-balada ini, ternyata sangat dibutuhkan oleh guru terutama SMA Negeri 1 Karangdowo Kabupaten Klaten. Pada tahap introduksi ditemukan banyak sekali permasalahan yang timbul. Antara lain adalah sebagian guru mengalami kendala dalam rangka mencari referensi sebagai sumber atau bahan ide untuk menulis artikel atau penelitian tindakan kelas (PTK). Hal ini diselesaikan dengan pendampingan penggunaan search engine melalui google schoolar atau google cendekia. 
Kegiatan ini sangat menarik karena sebagian guru yang bermula jarang menggunakan laptop atau komputer, menjadi semakin tertantang untuk menggali informasi sedalam-dalamnya melalui search engine dengan keyword sesuai minatnya.

Setelah guru menemukan materi atau bahan yang akan dijadikan sebagai ide untuk menulis, mereka dibekali bagaimana cara mendownload suatu artikel, dan menyimpan dalam repositorinya. Ide yang sudah ditemukan, dibuat suatu artikel dengan mensitasi artikel lain. Sitasi dilakukan dengan menggunakan zotero. Guru didampingi dalam rangka menginstal dan menggunakan aplikasi zotero ini. Penulisan referensi atau sitasi dilakukan secara urut dan sistematis, kemudian guru mengambil data berdasarkan topik atau tema yang diambil. Data yang sudah diambil kemudian diolah dengan menggunakan pengolah data statistik yaitu salah satunya dengan menggunakan software SPSS. Pendampingan pengolahan data dilakukan secara online maupun tatap muka, beserta interpretasi data yang diperoleh. Setelah mereka dapat menginterpretasikan data, maka didapatlah suatu kesatuan artikel yang siap untuk dipublikasikan. Gambaran kegiatan tersaji pada Gambar 1.
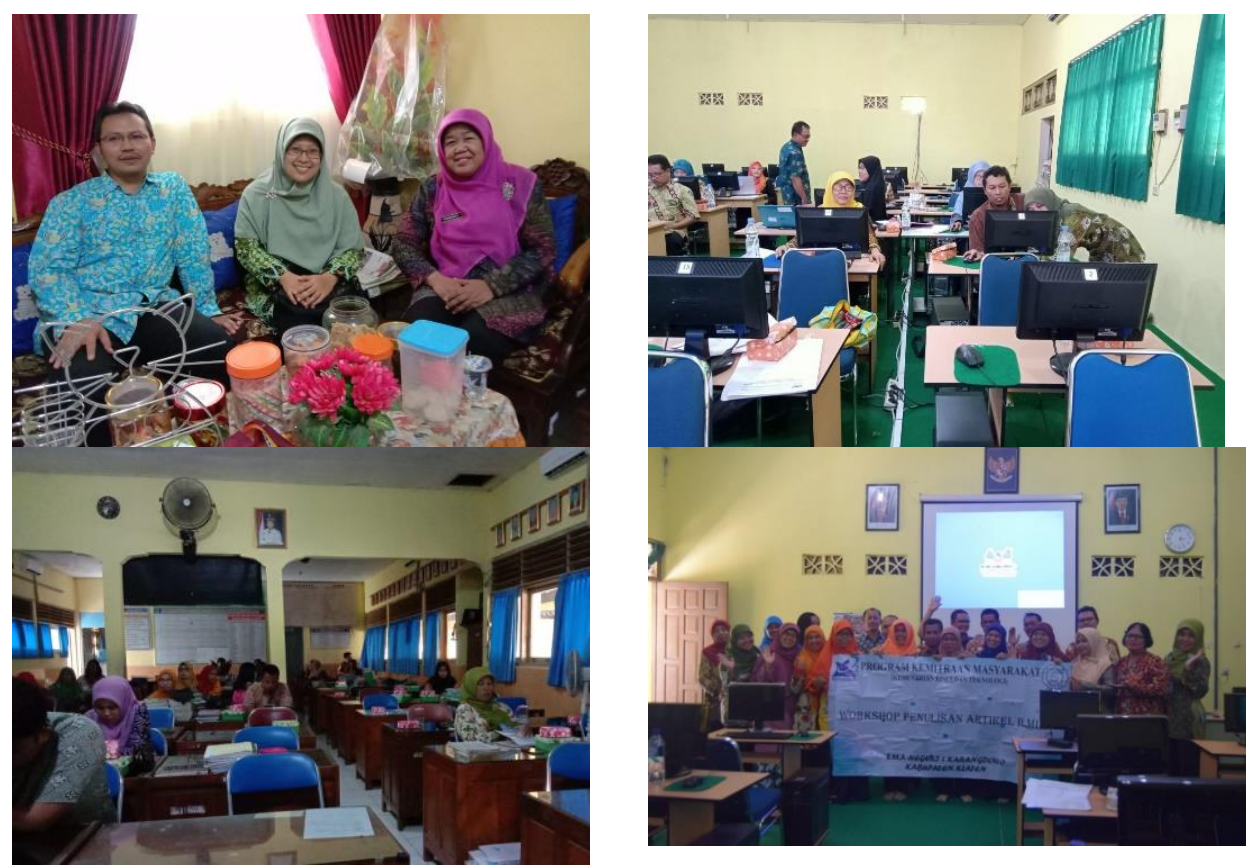

Gambar 1. Dokumentasi kegiatan dari tahap introduksi, edukasi, dan pendampingan E-balada

Kegiatan pendampingan E-balada ini memberikan kontribusi pada dunia pendidikan khususnya, dan segala aspek pengajaran pada umumnya. Pengetahuan tentang bagaimana cara membuat suatu artikel ilmiah maupun artikel penelitian sehingga dapat dimanfaatkan sebagai media untuk meningkatkan kompetensi. Model pembelajaran yang bisa digunakan juga sebagai referensi untuk diaplikasikan ketika mengajar di kelas. Hal ini bisa diimplikasikan sebagai bahan untuk membuat Penelitian Tindakan Kelas yang berkualitas maupun artikel ilmiah berbasis riset.

Pelaksanaan program Kemitraan Masyarakat di SMA Karangdowo memberikan dampak yang signifikan terhadap kompetensi guru, sehingga dapat menambah pengetahuan dan ketrampilan guru terutama dalam menulis artikel ilmiah. Gambar 1 menunjukkan serangkaian proses kegiatan program E-balada di SMA Negeri 1 Karangdowo Kabupaten Klaten. 


\section{SIMPULAN}

Program E-balada sangat berperan dan membantu guru dalam rangka meningkatkan kompetensinya. Kompetensi yang meningkat ini secara linear akan mempengaruhi profesionalisme dan kualitas guru dalam mengajar. Guru dapat memanfaatkan program Ebalada ini sebagai media untuk membuat artikel ilmiah dan dipublikasikan.

\section{UCAPAN TERIMAKASIH}

Terima kasih kami ucapkan kepada Direktorat Riset dan Pengabdian Masyarakat, Kementrian Riset Teknologi dan Pendidikan Tinggi yang telah memberikan dana hibah tahun anggaran 2018.Terima kasih juga kami sampaikan pada civitas akademika Universitas Sebelas Maret dan Universitas Muhammadiyah Surakarta, serta Mitra PKM SMA Negeri 1 Karangdowo Kabupaten Klaten Jawa Tengah.

\section{DAFTAR PUSTAKA}

Alam, S., (2015), Penulisan Artikel Ilmiah untuk Publikasi Ilmiah Melalui Jurnal, Artik. EBul., pp. 355-389.

Darmalaksana, W., (2017), Panduan Publikasi Ilmiah : Perangkat Aplikasi, Standar Penulisan dan Etika Kepengarangan, J. Ris. dan Inov., vol. 2, p. November.

Widoyoko, E., (2008)a, Penelitian Tindakan Kelas dan Pengembangan Profesi Guru, Semin. Nas. Peningkatan Kualitas Profesi Guru Melalui Penelit. Tindakan Kelas, Sep.

Widoyoko, E., (2008)b, Perananan Sertifikasi Guru dalam Meningkatkan Mutu Pendidikan, Semin. Nas. Peningkatan Kualitas Profesi Guru Melalui Penelit. Tindakan Kelas, Jul. 
